\title{
Spatial association between talc-rich mineralization and a "black smoker"-type deposit in a newly discovered inactive field (MARK area, Mid-Atlantic Ridge)
}

\author{
EWAN PELLETER * ${ }^{1}$, YVES FOUQUET ${ }^{1}$, AUDREY \\ BOISSIER $^{1}$, SANDRINE CHERON ${ }^{1}$, LAETITIA LEROY ${ }^{1}$, \\ YOAN GERMAIN $^{1}$, CECILE CATHALOT $^{1}$ AND \\ SCIENTFIC PARTIES
}

${ }^{1}$ IFREMER, Géosciences Marine, 29280 Plouzané, France

Since 1977 and the discovery of the first high temperature (HT) hydrothermal vent, more than 300 sites are known. Among these hydrothermal sites, the talc-rich deposit is the most recent class of hydrothermal system discovered on the seafloor [1]. Only three talc-rich deposits have been described so far: (i) the active Von Damm Vent Field (VDVF), (ii) the inactive St Paul's and (iii) Conrad fracture zones deposits [2]. These hydrothermal sites are associated with lower crustal rocks and/or serpentinized peridotites and might be widespread at slow or ultraslow spreading ridge. However, no clear spatial or temporal relationship of this new class of hydrothermal system and the "black smoker"-like system has been highlighted.

During the HERMINE cruise [3] (March-April 2017), an inactive hydrothermal area was discovered $28 \mathrm{~km}$ northwest of the Snake Pit vent field ( $25 \mathrm{~km}$ west of the axial rift). At least two deposits have been observed during a Nautile HOV dive. One of the deposits is composed of talc-rich rocks (up to $75 \%$ talc) and has geochemical characteristics similar to that of talc-rich deposits described in the literature. The other deposit located less than $1 \mathrm{~km}$ to the northeast is characterized by copper-rich mineralization (up to $3.3 \mathrm{wt} . \%$ ) similar to "blacksmoker"-like system. To our knowledge, this is the first time that such a spatial relationship has been described between these two classes of deposits. The preliminary result on this newly discovered inactive field will be presented here.

[1] Hodgkinson et al. (2015) Nat.. Commun 6:10150

doi: $10.1038 /$ ncomms 10150 .

[2] D’Orazio et al. (2004) Eur. J. Mineral. 16, 73-83

[3] Fouquet and Pelleter (2017),

https://doi.org/10.17600/17000200 